\title{
Ciguatera fish poisoning: A first epidemic in Germany highlights an increasing risk for European countries
}

\author{
César Mattei ${ }^{\mathrm{a}}$, Irina Vetter ${ }^{\mathrm{b}}$, Anneka Eisenblätter ${ }^{\mathrm{c}}$, Bernd Krock $^{\mathrm{d}}$, \\ Martin Ebbecke ${ }^{\mathrm{e}}$, Herbert Desel ${ }^{\mathrm{e}}$, Katharina Zimmermann ${ }^{\mathrm{c}, *}$ \\ a Laboratoire de Biologie Neurovasculaire et Mitochondriale Intégrée, CNRS UMR6214, INSERM U1083, Université d'Angers, Faculté de \\ Médecine, Angers, France \\ ${ }^{\mathrm{b}}$ Institute for Molecular Bioscience and School of Pharmacy, The University of Queensland, Brisbane, Australia \\ ${ }^{c}$ Klinik für Anästhesie am Universitätsklinikum Erlangen and Institut für Physiologie und Pathophysiologie, Friedrich-Alexander \\ Universität Erlangen-Nürnberg, Erlangen, Germany \\ d Alfred Wegener Institut, Helmholtz-Zentrum für Polar- und Meeresforschung, Bremerhaven, Germany \\ e Giftinformationszentrum-Nord (GIZ-Nord Poisons Center) and Institut für Pharmakologie und Toxikologie, Universitätsmedizin \\ Göttingen, Göttingen, Germany
}

\section{A R T I C L E I N F O}

\section{Article history:}

Received 14 August 2014

Received in revised form 15 October 2014

Accepted 21 October 2014

Available online 22 October 2014

\section{Keywords:}

Ciguatera

Ciguatoxins

Contaminated fish

Sea food intoxication

$\mathrm{Na}^{+}$channel

\begin{abstract}
A B S T R A C T
Toxin-producing microalgae are thriving worldwide due to coral reef destruction and global warming with major consequences on ecosystems, international trade and human health. Microalgae belonging to the family of flagellate protists, in particular dinoflagellates, secrete a variety of high-molecular-weight polyether toxins that accumulate through the marine food chain to cause disease in humans by acting as sodium channel activator toxins; ciguatera is the most frequent seafood-borne illness worldwide with 50,000 to 500,000 global incidences per annum and is usually limited to endemic areas located between $35^{\circ}$ northern and $35^{\circ}$ southern latitude. The rising global incidence frequency renders it a major human health problem, because no curative treatment is available yet and reliable detection assays are lacking. During the last decade ciguatera has increasingly become endemic in previously unaffected areas for two reasons: first global warming has contributed to the emergence of dinoflagellate species in subtropical and even temperate regions that previously had been constrained to tropical areas and second: in Europe globalization of fishing industry and tourism has led to a progressive increase in the number of ciguatera cases and a lack of awareness among medical personnel contributes to under-reporting. We review, through a recent ciguatera outbreak in Germany, the risk for ciguatera poisoning in Europe and highlight characteristic symptoms, current knowledge about disease pathomechanisms and treatment options.
\end{abstract}

(C) 2014 Elsevier Ltd. All rights reserved.

\section{Introduction}

\subsection{A global public health issue}

Ciguatera, a disease associated with a range of heterogeneous symptoms of neurological, gastrointestinal and

\footnotetext{
Abbreviations: CTX, ciguatoxin; C-CTX, Caribbean CTX; I-CTX, Indian Ocean CTX; P-CTX, Pacific CTX.

* Corresponding author.

E-mail address: katharina.zimmermann@fau.de (K. Zimmermann).
}

cardiovascular origin, is contracted by humans through the consumption of fish contaminated by ciguatoxins.

With an increasing global population, food security is becoming difficult to achieve in both emerging and developed countries. Fishery products supply millions of tons of fish worldwide to feed low-income populations of costal and insular areas, and provide an alternative protein source in Europe and America. This demand exerts rising pressure on fishing grounds, and in combination with globalization of trade, is leading to increased import and greater 
consumption of fish sourced from areas where ciguatera is endemic (Achaibar et al., 2007; Garcia and Rosenberg, 2010). Thus, the disease is no longer restricted to the South and Equatorial Pacific, the Caribbean Sea and the Indian Ocean (Bagnis et al., 1979; Lange, 1994), where several hundreds of fish species are known to harbor the toxins responsible for ciguatera.

While the European Union has adopted policies to ensure food safety, global mobility and intensive tourism to tropical and subtropical areas has led to an increased risk of contracting pathologies that rarely occur in temperate latitudes. In addition, the likelihood of contracting ciguatera in endemic areas is also increasing, as a continuous rise in poisoning cases has been reported since 1980 (Skinner et al., 2011). Epidemiological studies estimate that the annual incidence of ciguatera is about 50,000 cases of illness worldwide. However, this evaluation may be greatly underestimated as only $2-10 \%$ of cases are estimated to be reported to health authorities worldwide (Lehane and Lewis, 2000). Nonetheless, ciguatera is the most frequent non-bacterial food and seafood-related poisoning, with tourism and fish imports from endemic areas being the main causes for a continuous increase in cases in temperate latitudes (De Haro et al., 2003; Glaizal et al., 2011; Krause et al., 1994; Sanner et al., 1997; From the Centers for Disease Control and Prevention, 2013). To this effect, ciguatera has become a truly global human health concern.

\subsection{Ciguatera is increasing worldwide}

According to Johnson and Lange, the occurrence of ciguateric fish is restricted to tropical and subtropical marine areas between $35^{\circ}$ northern and $35^{\circ}$ southern latitude (Johnson and Jong, 1983; Lange, 1987). In subtropical climates, the presence of dinoflagellates is seasonal and likely affected by severe weather events. Worldwide, the Cook Islands in the Pacific appear as the area with the highest incidence (Rongo and van Woesik, 2013). A 2011 study estimated the lifetime risk for Cook Islanders to contract ciguatera as $>25 \%$ (Skinner et al., 2011). In recent years however, not only an increase in the incidence of ciguatera in endemic areas is observed, but also a higher incidence in subtropical regions and a spread of dinoflagellates into temperate climate zones, with ciguatoxic fish occurring near European coastlines and in the Mediterranean sea (Bentur and Spanier, 2007; Otero et al., 2010). Since 2010 at least three ciguatera outbreaks have been reported in the Canary Islands. These outbreaks coincided with the detection of novel toxin-producing dinoflagellates of the genus Gambierdiscus including Gambierdiscus excentricus (Fig. 1), and very recently Gambierdiscus silvae, which were identified off the Canary Island coastal waters (Boada et al., 2010; Nunez et al., 2012; Fraga and Rodríguez, 2014).

The Caribbean was previously considered as the only endemic area in the Atlantic Ocean, but recently, the occurrence of ciguatera was reported along the West Africa Coast, in particular the coastlines of Cameroon and Senegal (Glaizal et al., 2011; Bienfang et al., 2008). Ciguatera is also on the rise on the Asian continent with toxic micro-algae located on the Korean shorelines and around Jeju Island at $33^{\circ}$ northern latitude for the first time in 2011 (Jeong

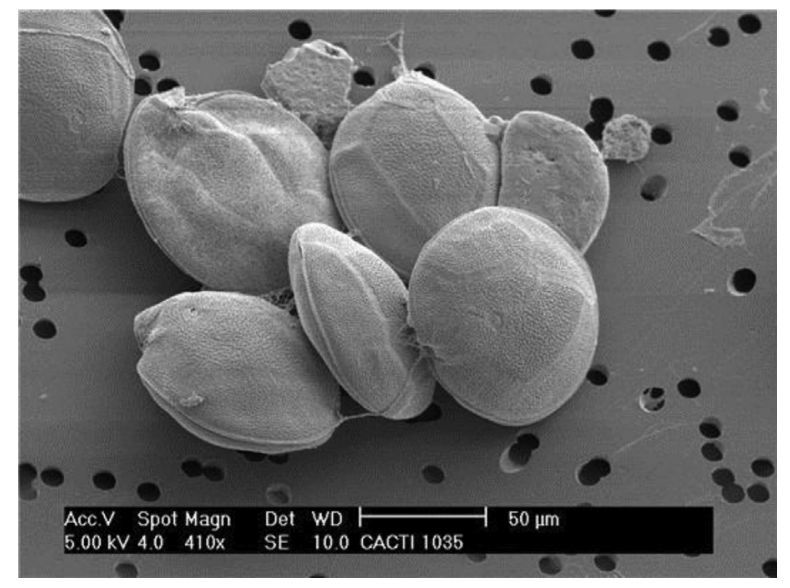

Fig. 1. Gambierdiscus excentricus, a novel type of toxic dinoflagellate detected in 2011 in waters off the Canary Islands by researchers at the Instituto Español de Oceanografía (Vigo, Spain). Dinoflagellates of the genus Gambierdiscus produce CTXs that accumulate in the food chain. Photography taken by Dr. Santiago Fraga, IEO Instituto Español de Oceanografía ${ }^{\odot}$.

et al., 2012). More recently, there were major outbreaks in temperate climates caused by imported contaminated fish, including 6 outbreaks in New York involving 28 poisoned persons between 2010 and 2011 (From the Centers for Disease Control and Prevention, 2013) and an outbreak in 2012 in northern Germany, where 20 cases were reported.

\subsection{Ciguatoxins - sodium channel toxins in the marine food chain}

Marine biotoxins produced by dinoflagellates are the causative agents in human ciguatera poisoning. Dinoflagellates are benthic single-cell organisms residing as epiphytes on damaged corals and contain ciguatoxins as metabolic products. Ciguatoxins (CTXs) are among the most potent neurotoxins. They accumulate through the food chain in herbivorous and carnivorous reef fish and reach highest concentrations in large predatory carnivorous fish. Host fish may be either insensitive to the toxic effects of ciguatoxins, as they appear to be free of symptoms, and instead accumulate the toxins in the flesh, viscera and liver. However, since ciguatera is rarely lethal in humans $(<1 \%)$, fish carrying particularly high levels of CTXs may be eliminated from the food chain early and thus restrict the doses consumed by humans to sub-lethal exposure. In contrast, freshwater fish appear more sensitive and CTXs can be lethal at lower concentrations (Lewis, 1992). An exception appears to be a reported high death rate (20\%) in Madagascar, after consumption of a ciguateric shark (Habermehl et al., 1994).

CTXs are high molecular weight, hydrophobic cyclic polyethers ( 1 kDa). CTXs are composed of 11-14 adjacent rings and are grouped in 3 subtypes, depending on their origin from the Pacific (P-CTX), the Indian Ocean (I-CTX) and the Caribbean (C-CTX). The chemical structure of PCTX-1B is shown in Fig. 2 (Murata et al., 1990; Lewis et al., 1991). In general, P-CTXs are considered the most potent, with humans exhibiting symptoms at $0.1 \mathrm{ppb}(0.1 \mathrm{ig} / \mathrm{kg})$; they are approximately 10 -fold more potent than the 


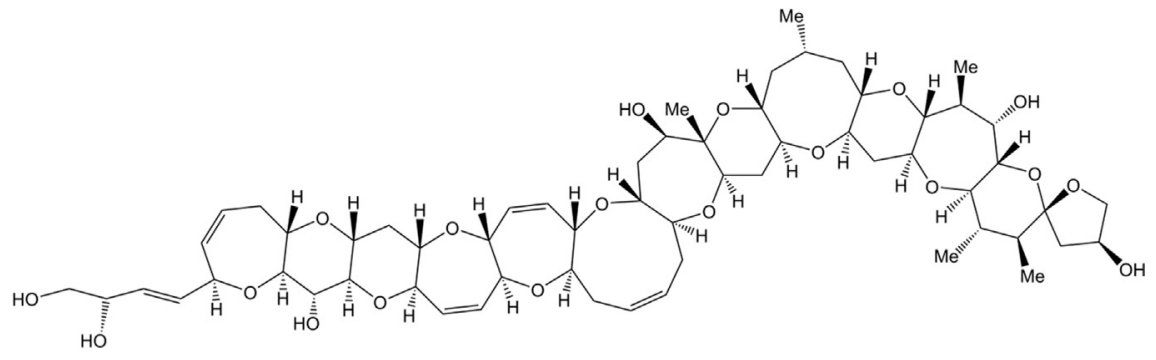

Fig. 2. Structure of P-CTX-1B (Murata et al., 1990; Lewis et al., 1991).

Caribbean variants, and frequently cause severe neurological symptoms (Friedman et al., 2008). The toxicity of the four described I-CTXs variants is estimated at about $60 \%$ of the P-CTXs (Hamilton et al., 2002).

Ciguateric fish cannot be distinguished from non-toxic fish, neither by texture, smell nor taste and CTXs are indestructible by heating, freezing or gastric acid and virtually non-perishable in frozen fish, which is why intoxications may occur anywhere through import of contaminated fish. According to Gillespie, more than 400 species from 57 families and 11 orders are described as CTX carriers (Gillespie et al., 1986). Table 1 lists the most common fish that caused poisoning in recent years. Mechanistically, CTXs occupy binding site 5 of the mammalian voltage-gated sodium channels, which is located in the vicinity of the pore leading to channel activation of mainly neuronal, and to a lesser extent muscular and cardiac, sodium channel subtypes (Bidard et al., 1984; Lombet et al., 1987). CTXs inhibit $\mathrm{Na}^{+}$channel inactivation and shift their voltage dependence towards more negative potentials. Additionally they act as voltage-gated $\mathrm{K}^{+}$channel inhibitors (Birinyi-Strachan et al., 2005; Schlumberger et al., 2010). As a result, membrane potential oscillations emerge which in turn lead to sensitization of transducer ion channels, like cold-sensitive TRPA1 and potentially TRPV1 which may explain some of the sensory symptoms associated with ciguatera (Vetter et al., 2012).

\section{Ciguatera in Germany}

\subsection{Ciguatera outbreaks}

In most European countries, ciguatera is considered an exotic disease, and is included in the field of tropical and travel medicine (De Haro et al., 1997; Glaizal et al., 2011). Between 2000 and 2013, 61 cases were registered in Germany, which were related to travels in endemic areas (Zimmermann et al., in press).

In 2009 in the port of Hamburg, the Filipino crew of a container ship under Bahamian flag en route from South America to Germany consumed fish caught in the Caribbean and all sailors bar one - who had not eaten the fish suffered from ciguatera. Once in Hamburg, they received medical treatment. The fish involved in this ciguatera outbreak was later identified as Red grouper (Cephalopholis miniata) and Bigeye Trevally (Caranx sexfasciatus) (Schlaich et al., 2012). For the first time in Germany, a larger ciguatera outbreak occurred more recently through the consumption of fresh fish imported from South Indian fishing grounds, with 20 patients affected mainly in northern Germany. These cases were reported to the GIZ-Nord Poisons Center in November 2012 and evaluated in detail in terms of their symptoms and initial treatment. However, the suspicion of a high number of unreported cases is warranted given that ciguatera can be difficult to diagnose, and in contrast for example to the United States, poisoning is not subject to mandatory reporting in Germany.

\subsection{Samples of red snapper sold in Germany contained P- CTXs}

After the first cases of ciguatera emerged in early November 2012 and were reported to the regional Poison Control Centres, the imported contaminated fish was immediately recalled. Local food control laboratories located in states where cases occurred sent contaminated fish samples to the national reference laboratory (NRL) for marine biotoxins at the Federal Institute for Risk Assessment (BfR) in Berlin. As no methods for CTX analysis were available at the German NRL, the samples were forwarded to the European Union Reference Laboratory for Marine Biotoxins (EURLMB) in Vigo, Spain and the putatively contaminated fish samples were analyzed by liquid chromatography-tandem mass spectrometry (LC-MS/MS) according to a method published by (Yogi et al., 2011) with slight modifications. The only available analytical standard was P-CTX-1B. Seven out of eleven samples tested positive for P-CTX-1B. In addition, other putative CTX variants were detected across most samples, however, could not be confirmed as CTXs due to the lack of reference compounds. The original data belong to the official state offices for consumer protection and food safety of the states of Schleswig-Holstein, Hamburg, Lower Saxony and Bavaria, the BfR and the EURLMB. The affected fish originated from Sri Lankan fishing grounds, where some areas were affected by three subsequent heavy cyclones in summer and autumn 2012. Cyclones entail destruction of coral reefs and lead to increased oxygen concentration in the water, which in combination with warm water temperature favors algal bloom and as a result promotes thriving of toxinproducing dinoflagellates. In fact, a recently published study showed that the occurrence of ciguateric fish is not correlated with coral growth, but rather with reef bleaching which also increases the incidence of Ctenochaetus striatus, the striated surgeonfish, a tropical herbivorous fish (Rongo and van Woesik, 2013). Intact corals may carry an 
Table 1

Fish species that may contain CTXs. More than 400 fish species can be a vector for CTXs, but only a relatively small number are permanently ciguateric and must to be avoided.

\begin{tabular}{|c|c|c|c|}
\hline Latin name & Common name & Reference & Geographic area \\
\hline $\begin{array}{l}\text { Lutjanus spp. } \\
\sim \text { bohar } \\
\sim \text { sebae } \\
\sim \text { gibbus } \\
\sim \text { monostigma }\end{array}$ & $\begin{array}{l}\text { Snappers, sweetlips } \\
\text { Red bass, Red emperor, } \\
\text { Paddle tail }\end{array}$ & $\begin{array}{l}\text { Pottier et al., 2002a } \\
\text { Beaglehole, 1961; Oshiro et al., 2010; } \\
\text { Hsieh et al., 2009; Yogi et al., } 2013\end{array}$ & $\begin{array}{l}\text { Guadeloupe } \\
\text { New Hebrides, Okinawa, Amami and } \\
\text { Kakeroma (Japan), Taiwan }\end{array}$ \\
\hline Carcharhinus amboinensis & Pigeye shark & $\begin{array}{l}\text { Habermehl et al., 1994; Ramialiharisoa } \\
\text { et al., } 1997\end{array}$ & Madagascar \\
\hline Gymnothorax spp. & Moray eel & $\begin{array}{l}\text { Lewis et al., 1991; Oshiro et al., 2010; } \\
\text { Bourdeau and Bagnis, } 1989\end{array}$ & $\begin{array}{l}\text { Kiribati, } \\
\text { Okinawa (Japan), French West Indies }\end{array}$ \\
\hline $\begin{array}{l}\text { Sphyraena spp. } \\
\text { jello } \\
\text { barracuda }\end{array}$ & Barracuda & $\begin{array}{l}\text { Lewis and Endean, 1984b; Pottier et al., 2003; } \\
\text { De Haro et al., 1997; Morton and Burklew, } \\
\text { 1970; Morris et al., 1990; Bourdeau, } 1992\end{array}$ & $\begin{array}{l}\text { Mexico, Australia, Guadeloupe, } \\
\text { USA (Florida, North Carolina), } \\
\text { French West Indies }\end{array}$ \\
\hline $\begin{array}{l}\text { Plectropomus spp. } \\
\text { leopardus } \\
\sim \text { areolatus }\end{array}$ & Coral trout & Wong et al., 2005; Oshiro et al., 2010 & Hong Kong, Okinawa (Japan) \\
\hline 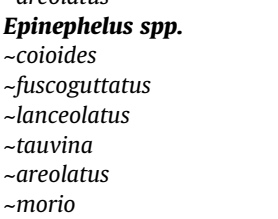 & $\begin{array}{l}\text { Reef cods } \\
\text { Rock cod } \\
\text { Grouper } \\
\text { Flowery cod }\end{array}$ & $\begin{array}{l}\text { Wong et al., 2005; Luo et al., 2011; } \\
\text { Oshiro et al., 2010; Bagnis et al., 1979; } \\
\text { From the Centers for Disease Control } \\
\text { and Prevention, 2013; Bourdeau, } 1992\end{array}$ & $\begin{array}{l}\text { Hong Kong, Xiamen (China), } \\
\text { Okinawa (Japan), French West } \\
\text { Indies, New York }\end{array}$ \\
\hline $\begin{array}{l}\text { Cheilinus spp } \\
\sim \text { undulates } \\
\sim \text { trolobatus } \\
\sim \text { undulatus }\end{array}$ & Humphead wrasse & Chan, 2013 & Hong Kong \\
\hline Choerodon spp. & Tuskfish & Gillespie et al., 1986 & Queensland (Australia) \\
\hline $\begin{array}{l}\text { Seriola spp. } \\
\sim \text { dumerili } \\
\sim \text { fasciata }\end{array}$ & $\begin{array}{l}\text { Amberjack } \\
\text { Kingfish }\end{array}$ & $\begin{array}{l}\text { Nunez et al., 2012; } \\
\text { Boada et al., 2010; Otero et al., 2010; } \\
\text { Poli et al., 1997; Bourdeau and Bagnis, } 1989\end{array}$ & $\begin{array}{l}\text { Canary Islands, Madeira, } \\
\text { Haiti, French West Indies }\end{array}$ \\
\hline $\begin{array}{l}\text { Scomberomorus spp. } \\
\sim \text { munroi } \\
\sim \text { commersoni }\end{array}$ & $\begin{array}{l}\text { Spanish mackerel, } \\
\text { Spotted mackerel }\end{array}$ & Endean et al., 1993; Gillespie et al., 1986 & Queensland (Australia) \\
\hline $\begin{array}{l}\text { Scomberoides spp. } \\
\text { Caranx spp. } \\
\text { ignobilis } \\
\text { melampygus } \\
\text { sexfasciatus } \\
\text { - latus } \\
\text {; bartholomaei }\end{array}$ & $\begin{array}{l}\text { Queenfish } \\
\text { Trevally, Bigeye Trevally, } \\
\text { Horse-eye jack }\end{array}$ & $\begin{array}{l}\text { Mitchell, } 1976 \\
\text { Pottier et al., 2002b; Schlaich et al., 2012; } \\
\text { Bourdeau, 1992; Vernoux and Lewis, } 1997\end{array}$ & $\begin{array}{l}\text { Queensland (Australia) } \\
\text { West Indies }\end{array}$ \\
\hline Cephalopholis miniata & Red grouper, Coral cod & Schlaich et al., 2012 & West Indies \\
\hline Variola louti & Yellow-edged lyretail & Glaizal et al., 2011; Oshiro et al., 2010 & Mauritius, Okinawa (Japan) \\
\hline Lachnolaimus maximus & Hogfish & Bourdeau and Bagnis, 1989 & West Indies \\
\hline Symphorus nematophorus & Chinaman cod & Lewis and Endean, 1984a & Queensland (Australia) \\
\hline Rachycentron canadus & Cobia & Lewis and Endean, 1984a & Queensland (Australia) \\
\hline Lethrinus spp. & Emperor & Whitley, 1943 & Queensland (Australia) \\
\hline Polydactylus quadrifilis & African threadfin & Glaizal et al., 2011 & Senegal \\
\hline
\end{tabular}

antimicrobial lining preventing algal overgrowth. In fact, while cyclones are common in the Indo-Pacific area, they are triggers for the domestic population to avoid eating fish up to several weeks after such an event (Glaizal et al., 2011).

\subsection{Patients, diagnosis and initial treatment}

A total of 19 patients contacted either Deutsche See, the vendor of the contaminated fish products, or the GIZ-Nord Poisons Center a few hours to days after the consumption of fish, although an unknown number of undiagnosed cases is suspected. Reported cases occurred in urban areas of Hamburg (4), Kiel (7), Celle (2), Bad Kreuznach (2), Mainz (2) and in the state of Bavaria (2). In December 2012, approximately four weeks after beginning of disease symptoms, we sent questionnaires with questions about initial treatment and symptomatology to 14 of the 20 affected people. All patients still suffered from neurological ciguatera symptoms. 11 patients returned the questionnaire ( 4 females and 7 males). Each of them had consumed between 80 and $300 \mathrm{~g}$ of red snapper (Lutjanus malabaricus). The patients were predominantly adults between 38 and 76 years of age and the majority ( 7 patients) were above 60 . Some suffered from pre-existing diseases such as diabetes and coronary heart disease. The initial symptoms were similar in all patients: about 45 min after consumption of fish the majority (6/11) felt a burning sensation in the mouth. After 4-12 h, diarrhea (10/11) and/or nausea (6/ 11) accompanied by vomiting (5/11) evolved. After the acute gastrointestinal toxicity phase had faded, all patients complained of feeling cold which is characteristic of ciguatera, and was present in $10 / 11$ patients. According to the literature, a drop in body temperature - likely due to central nervous system effects (Gatti et al., 2008) - is a 
common symptom of ciguatera and has been experimentally reproduced in rodents (Bottein Dechraoui et al., 2008). Furthermore, the majority of patients (7/11) complained about diffuse pruritus within $24 \mathrm{~h}$ after the fish meal. Three patients developed pruritus later during the disease. All intoxicated patients except for one received medical treatment within the first four days after fish consumption. In most cases, the family physician was visited, but one couple called an ambulance and was hospitalized because of strong vegetative symptoms including hypotension and repetitive fainting. In fact, in some ciguatera cases early cardiovascular symptoms can dominate the disease with potentially life-threatening bradycardia and hypotension, and may require the use of atropine, hydration and inotropic drugs (Chan and Wang, 1993; Chan, 2013; Hung et al., 2005; Senthilkumaran et al., 2011). For these two patients, the diagnosis was gastroenteritis caused by enterotoxins due to the history of fish consumption. However, both self-diagnosed ciguatera retrospectively based on an internet search, as did six other patients including two married couples. A fourth couple self-diagnosed ciguatera before visiting a physician. A 76-year old patient decided to refrain from seeking medical attention based on internet information that advised that it would have been too late for mannitol infusion therapy. Time to diagnosis exceeded $48 \mathrm{~h}$ for all patients. Only one patient received mannitol infusion for treatment, while in 6 cases, clinical, ultrasound and/or laboratory examinations were carried out but no specific treatment was initiated. Another patient was treated with an antihistamine for suspected allergy, while the hospitalized coupled received intravenous fluid support. Although the majority of medical staff involved in diagnosis and treatment misdiagnosed the condition, 8 patients thought this was understandable given the initial non-specific gastrointestinal symptoms, the generally low incidence of ciguatera in central Europe and the ensuing low awareness about the disease. Only three patients stated they were dissatisfied with their medical treatment.

\subsection{Long-lasting ciguatera symptoms}

In the majority (9/11) of cases, gastrointestinal symptoms subsided within one week. However, non-specific central, sensory and vegetative symptoms persisted and remained present at the time of the interview, which was $6-8$ weeks after the intoxication. A few patients still suffered from pruritus 1 year after the poisoning. Central neurological symptoms included fatigue (7/11), difficulty sleeping (7/11), dizziness (7/11), lack of concentration (6/11), word-finding difficulty (5/11), reduced mental capacity (5/11) and unsteadiness (5/11), all of which are commonly described in ciguatera. Five patients described persistent metallic taste and about half complained of respiratory problems, either as shortness of breath or swollen mucous membranes. This pathology resolved spontaneously within three weeks. All patients experienced long-lasting general weakness, accompanied by reduced physical capacity, and abnormal fatigability existed for several months in some cases.

Ten patients complained for at least one -on average three and a half- weeks about feeling cold and experiencing persistant pruritus. In almost all patients, burning pain in combination with cooling of the skin, so-called cold allodynia, was present. Both pruritus and cold allodynia located predominantly to the periphery of upper and lower extremities. Bodily distribution of both symptoms is illustrated in Fig. 3.

This distribution shows strong similarity to the distribution of distal axonal polyneuropathies, so-called "dying back neuropathies", and is in agreement with description in the literature (Schnorf et al., 2002). Hence, ciguatera neuropathy exhibits sensory disturbances of both large and small diameter fibers, with dysfunction mainly affecting small fibers. Overall, there was a strong variation in the frequency and intensity of symptoms which is also in accordance with epidemiological data (Bagnis et al.,1979). The reasons for this may be multifactorial: it is known that individual or hereditary sensitivity for CTXs, as well as amount and subtypes of toxins ingested contribute to the variability of symptoms.

Cold allodynia, pruritus, tingling paresthesia, and variable pain symptoms are considered to be characteristic of ciguatera poisoning. Cold allodynia - some patients describe it as a reversal of temperature sensing - is considered pathognomonic (Vetter et al., 2012; Zimmermann et al., 2013) and affects especially perioral areas, as well as the peripheral parts of the extremities. Published studies mention cold allodynia at a frequency of up to $94 \%$, with pruritus occurring in up to $76 \%$ of ciguatera patients (Table 2). Although the incidence and severity of neurological symptoms is diverse, essentially all ciguatera victims suffer from paresthesias or diffuse pain, including myalgia, arthralgia, tooth pain or headache (Table 2); in addition, hypothermia is common in ciguatera. Thus, the presence of some or all the above symptoms in combination with recent fish consumption should lead to consideration of ciguatera as the differential diagnosis.

\section{Ciguatera symptoms and therapeutical options}

\subsection{Ciguatera symptoms tend to become chronic and CTX re- exposure leads to recurrent symptoms}

One of the distinctive features of ciguatera is the persistence of neurological symptoms, which can last for months with recurrent paroxysmal periods even after years. The recurrence of symptoms, like pruritus, may be triggered by certain environmental factors and behaviors (Friedman et al., 2008). Therefore, patients are often encouraged to avoid alcohol, caffeine, exercise or activities that can lead to dehydration as well as consumption of fish for several months, as these have been reported to be associated with an increased risk of symptom recurrence.

However, these recommendations are based on isolated case reports rather than systematic clinical studies. Similarly, case reports suggest that subsequent ciguatera poisoning can be associated with more severe symptomatology than the primary intoxication. For instance, in 2010 a French couple experienced ciguatera poisoning in Mauritius and both were again exposed to CTXs during a stay in Senegal one year later, where they consumed servings of some large giant African threadfin (Polydactylus quadrifilis). The couple suffered from gastrointestinal symptoms followed by neurological symptoms that lasted for up to 11 days. Remarkably, none of the other guests who 

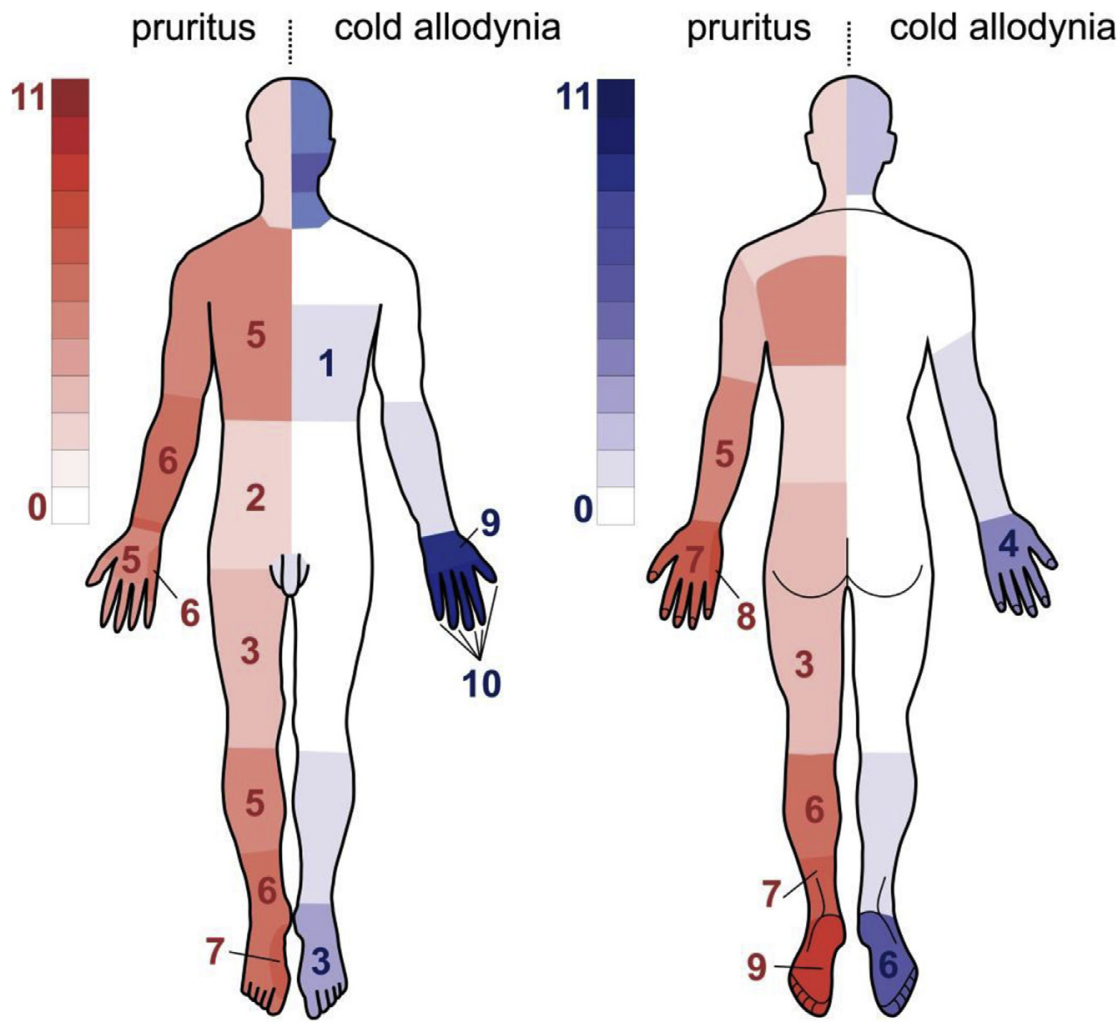

Fig. 3. Schematic representation of the distribution of cold allodynia (blue) and pruritus (red) on the body. In almost all patients, cold allodynia appears mainly confined to the hands and feet, especially the soles of the feet. Unlike cold allodynia, pruritus was more diffusely distributed at the time of the observation. The number of patients with symptoms $(n=11)$ was differentiated by gradation of blue and red values.

ate from the same fish experienced any ciguatera symptoms (Glaizal et al., 2011). Recurrence of ciguatera symptomatology in previously asymptomatic subjects has been reported frequently (Dickey and Plakas, 2010; Vigneau et al., 2008). It is possible that the highly lipophilic CTXs persist on axonal membranes where they cause a distal axonal channelopathy. In addition, it is likely that due to their lipophilicity, CTXs accumulate in body fat from where they are only slowly eliminated. A second exposure to

Table 2

Clinical symptoms of ciguatera. Shown is the reported frequency (\%) of clinical symptoms at the time of diagnosis according to (Friedman et al., 2008; Lange, 1994).

\begin{tabular}{ll}
\hline Symptoms & Frequency\% \\
\hline Neurological & \\
Cold allodynia & $76-94$ \\
Paresthesias & $72-100$ \\
Arthralgia, myalgia & $56-83$ \\
Pruritus & $42-76$ \\
Headache & $50-62$ \\
Fatigue, asthenia & $60-100$ \\
Dental pain & $21-37$ \\
Dysuria & $13-33$ \\
Gastrointestinal & \\
Diarrhea & $50-75$ \\
Nausea & $26-82$ \\
Abdominal pain & $43-75$ \\
Cardiovascular & \\
Bradycardia & 12 \\
Hypertension & 16 \\
\hline
\end{tabular}

significantly lower doses, or secondary insults affecting neuronal function, could then lead to recurrence of symptoms as no "loading dose" is required to achieve sufficient accumulation of CTXs in fat depots.

In about $5 \%$ of cases, acute ciguatera results in a longlasting disease, which carries features of a systemic immune response and is referred to as chronic ciguatera. Symptoms include general asthenia, cognitive impairment, chronic pain as well as shortness of breath. Neurological symptoms from the acute stage may persist. A recent study identified predictive factors for the development of chronic ciguatera and recommended the measurement of specific biological markers which may support the diagnosis of chronic ciguatera. These markers include for instance the presence of certain HLA DR Haplotypes (such as HLA-DRB1 4) which may also be present in patients with Lyme disease or rheumatoid arthritis (Shoemaker et al., 2010).

\subsection{Therapeutical options}

Apart from early ( $<60 \mathrm{~min}$ ) removal of toxins by vomiting and gastric lavage which may be difficult to achieve and is not routinely recommended due to the highly variable, and often inefficient, removal of toxins, therapeutic options are limited and medical management of ciguatera remains largely symptomatic.

In endemic areas, phytotherapeutics are often prescribed; however their efficacy has not yet been systematically studied in clinical trials (Kumar-Roine et al., 2011). 
Mannitol infusion remains a therapeutic option, if administered early, although the studies reporting efficacy in reversing neurological symptoms were largely based on a small number of cases, all of which were either uncontrolled or only randomized (Stewart, 1991). A randomized doubleblind study carried out in 2002 in Rarotonga (Cook Islands) compared intravenous mannitol with Ringer's solution and reported a reduction of neurological symptoms in both groups by about half after $24 \mathrm{~h}$, although overall no significant benefit was associated with the use of mannitol (Schnorf et al., 2002). Nevertheless, mannitol infusion was recommended as the first option for treatment within 48-72 h after a fish meal in case of no contraindications (Friedman et al., 2008). Repeated mannitol infusions have not been tested in a double blind study. Results of a cumulative clinical case series suggest that the bile acid binding resin cholestyramine might be effective in ciguatera. The Center for Research on Biotoxin Associated Illnesses (Pocomoke, USA) reported successful treatment of more than 200 ciguatera patients with cholestyramine since 1999. Cholestyramine was associated with positive effects if given early after the first symptoms, although effects declined in illness of longer duration (Shoemaker et al., 2010). Interestingly, cholestyramine at a dose of $1-2 \mathrm{~g}$ q.i.d. (max. $16 \mathrm{~g} / \mathrm{d}$ ) is also used in the treatment of cholestatic pruritus with considerable success (Van Itallie et al., 1961).

Brevetoxins (from the dinoflagellate Karenia brevis), polyether toxins which are structurally similar to CTXs, are bound to high-density lipoproteins in plasma of ciguatera victims (Woofter and Ramsdell, 2007) which suggests that CTXs or other polyether toxins may undergo enterohepatic recirculation. Accordingly, cholestyramine may accelerate elimination of these toxins, leading to earlier abatement of symptoms and prevention of progression to chronic ciguatera. In mild cases, cholestyramine in conjunction with mannitol might be considered as an early therapy to relieve symptoms, while in severe cases associated with significant cardiovascular symptoms, lipid apheresis might be considered as an experimental treatment. Physicians who suspect ciguatera should immediately inform their regional Poison Control Centre, which may be able to assist with confirmation of diagnosis, track and recall affected fish products to limit ciguatera epidemics, and send samples for analysis.

\section{Conclusion}

Although known since the 18th century, ciguatera is still a major challenge today. There is a lack of robust diagnostic tests; no reliable screening method exists to identify contaminated fish; the disease often leads to protracted morbidity and no specific cure or effective treatment is available, limiting therapeutic options. Since only a few countries have established mandatory reporting of ciguatera, it is very difficult to achieve epidemiological and clinical studies with sufficient case numbers in Europe. On the other hand, health care facilities and capacity for larger randomized controlled trials are usually limited in endemic areas. An increase in cases in central Europe can be expected based on increasing globalization and climate change.

\section{Conflict of interest}

The authors declare that they have no conflict of interest.

\section{Acknowledgments}

The patient study was supported by the EFIC Gruenenthal Grant 2012 (KZ). The authors would like to thank Dr. Maria Koch (Deutsche See) for critical discussions.

\section{Transparency document}

Supplementary data related to this article can be found at http://dx.doi.org/10.1016/j.toxicon.2014.10.016.

\section{References}

Achaibar, K.C., Moore, S., Bain, P.G., 2007. Ciguatera poisoning. Pract Neurol. 7, 316-322.

Bagnis, R., Kuberski, T., Laugier, S., 1979. Clinical observations on 3,009 cases of ciguatera (fish poisoning) in the South Pacific. Am. J. Trop. Med. Hyg. 28, 1067-1073.

Beaglehole, J.C., 1961. The Journals of Captain James Cook on His Voyages of Discovery: the Voyage of the Resolution and Adventure 1772-1775. Cambridge University Press, Cambridge.

Bentur, Y., Spanier, E., 2007. Ciguatoxin-like substances in edible fish on the eastern Mediterranean. Clin. Toxicol. (Phila) 45, 695-700.

Bidard, J.N., Vijverberg, H.P., Frelin, C., Chungue, E., Legrand, A.M. Bagnis, R., Lazdunski, M., 1984. Ciguatoxin is a novel type of $\mathrm{Na}$ channel toxin. J. Biol. Chem. 259, 8353-8357.

Bienfang, P., Oben, B., DeFelice, S., Moeller, P., Huncik, K., Oben, P. Toonen, R., Daly-Engel, T., Bowen, B., 2008. Ciguatera: the detection of neurotoxins in carnivorous reef fish from the coast of Cameroon, West Africa. Afr. J. Mar. Sci. 30, 533-540.

Birinyi-Strachan, L.C., Gunning, S.J., Lewis, R.J., Nicholson, G.M., 2005. Block of voltage-gated potassium channels by Pacific ciguatoxin-1 contributes to increased neuronal excitability in rat sensory neurons. Toxicol. Appl. Pharmacol. 204, 175-186.

Boada, L.D., Zumbado, M., Luzardo, O.P., Almeida-Gonzalez, M. Plakas, S.M., Granade, H.R., Abraham, A., Jester, E.L., Dickey, R.W., 2010. Ciguatera fish poisoning on the West Africa Coast: an emerging risk in the Canary Islands (Spain). Toxicon 56, 1516-1519.

Bottein Dechraoui, M.Y., Rezvani, A.H., Gordon, C.J., Levin, E.D., Ramsdell, J.S., 2008. Repeat exposure to ciguatoxin leads to enhanced and sustained thermoregulatory, pain threshold and motor activity responses in mice: relationship to blood ciguatoxin concentrations. Toxicology 246, 55-62.

Bourdeau, P., 1992. Ciguatoxic fish in the French West Indies. Bull. Soc Pathol. Exot. 85, 415-418.

Bourdeau, P., Bagnis, R., 1989. Risk factors of ciguatera in the French West Indies in Saint-Barthelemy, Saint-Martin and Anguilla. Rev. Elev. Med. Vet. Pays Trop. 42, 393-410.

Chan, T.Y., 2013. Ciguatera caused by consumption of humphead wrasse Toxicon 76, 255-259.

Chan, T.Y., Wang, A.Y., 1993. Life-threatening bradycardia and hypotension in a patient with ciguatera fish poisoning. Trans. R. Soc. Trop. Med Hyg. 87, 71.

De Haro, L., Hayek-Lanthois, M., Joossen, F., Affaton, M.F., Jouglard, J., 1997. Mass ciguatera poisoning after eating barracuda in Mexico: prognostic and therapeutic implications. Med. Trop. (Mars) 57, 55-58.

De Haro, L., Pommier, P., Valli, M., 2003. Emergence of imported ciguatera in Europe: report of 18 cases at the Poison Control Centre of Marseille. J. Toxicol. Clin. Toxicol. 41, 927-930.

Dickey, R.W., Plakas, S.M., 2010. Ciguatera: a public health perspective. Toxicon 56, 123-136.

Endean, R., Griffith, J.K., Robins, J.J., Monks, S.A., 1993. Multiple toxins in a specimen of the narrow-barred Spanish mackerel, Scomberomorus commersoni. Toxicon 31, 195-204.

Fraga, S., Rodríguez, F., 2014. Genus Gambierdiscus in the Canary Islands (NE Atlantic Ocean) with Description of Gambierdiscus silvae sp. nov. a New Potentially Toxic Epiphytic Benthic Dinoflagellate, Protist. http://dx.doi.org/10.1016/j.protis.2014.09.003.

Friedman, M.A., Fleming, L.E., Fernandez, M., Bienfang, P., Schrank, K, Dickey, R., Bottein, M.Y., Backer, L., Ayyar, R., Weisman, R., Watkins, S. 
Granade, R., Reich, A., 2008. Ciguatera fish poisoning: treatment, prevention and management. Mar. Drugs 6, 456-479.

From the Centers for Disease Control and Prevention, 2013. Ciguatera fish poisoning - New York city, 2010-2011. MMWR Morb. Mortal. Wkly. Rep 62, 61-65.

Garcia, S.M., Rosenberg, A.A., 2010. Food security and marine capture fisheries: characteristics, trends, drivers and future perspectives. Philos. Trans. R. Soc. Lond B Biol. Sci. 365, 2869-2880.

Gatti, C., Oelher, E., Legrand, A.M., 2008. Severe seafood poisoning in French Polynesia: a retrospective analysis of 129 medical files. Toxicon 51, 746-753.

Gillespie, N.C., Lewis, R.J., Pearn, J.H., Bourke, A.T., Holmes, M.J., Bourke, J.B., Shields, W.J., 1986. Ciguatera in Australia. Occurrence, clinical features, pathophysiology and management. Med. J. Aust. 145, 584-590.

Glaizal, M., Tichadou, L., Drouet, G., Hayek-Lanthois, M., de, H.L., 2011. Ciguatera contracted by French tourists in Mauritius recurs in Senegal. Clin. Toxicol. (Phila) 49, 767.

Habermehl, G.G., Krebs, H.C., Rasoanaivo, P., Ramialiharisoa, A., 1994. Severe ciguatera poisoning in Madagascar: a case report. Toxicon 32, 1539-1542.

Hamilton, B., Hurbungs, M., Jones, A., Lewis, R.J., 2002. Multiple ciguatoxins present in Indian Ocean reef fish. Toxicon 40, 1347-1353.

Hsieh, C.H., Hwang, K.L., Lee, M.M., Lan, C.H., Lin, W.F., Hwang, D.F., 2009. Species identification of ciguatoxin-carrying grouper implicated in food poisoning. J. Food Prot. 72, 2375-2379.

Hung, Y.M., Hung, S.Y., Chou, K.J., Huang, N.C., Tung, C.N., Hwang, D.F., Chung, H.M., 2005. Short report: persistent bradycardia caused by ciguatoxin poisoning after barracuda fish eggs ingestion in southern Taiwan. Am. J. Trop. Med. Hyg. 73, 1026-1027.

Jeong, H.J., Lim, A.S., Jang, S.H., Yih, W.H., Kang, N.S., Lee, S.Y., Yoo, Y.D., Kim, H.S., 2012. First report of the epiphytic dinoflagellate Gambierdiscus caribaeus in the temperate waters off Jeju Island, Korea: morphology and molecular characterization. J. Eukaryot. Microbiol. 59, 637-650.

Johnson, R., Jong, E.C., 1983. Ciguatera: Caribbean and Indo-Pacific fish poisoning. West J. Med. 138, 872-874.

Krause, G., Andersch-Borchert, I., Diesfeld, H.J., 1994. Ciguatera. New cases of fish poisoning in German Caribbean vacationers. Dtsch. Med. Wochenschr. 119, 975.

Kumar-Roine, S., Taiana, D.H., Matsui, M., Fabre, N., Haddad, M., Chinain, M., Pauillac, S., Laurent, D., 2011. A review of traditional remedies of ciguatera fish poisoning in the Pacific. Phytother. Res. 25, 947-958.

Lange, W.R., 1987. Ciguatera toxicity. Am. Fam. Physician 35, 177-182.

Lange, W.R., 1994. Ciguatera fish poisoning. Am. Fam. Physician 50, 579-584.

Lehane, L., Lewis, R.J., 2000. Ciguatera: recent advances but the risk remains. Int. J. Food Microbiol. 61, 91-125.

Lewis, R.J., 1992. Ciguatoxins are potent ichthyotoxins. Toxicon 30, 207-211.

Lewis, R.J., Endean, R., 1984. Ciguatoxin from the flesh and viscera of the barracuda, Sphyraena jello. Toxicon 22, 805-810.

Lewis, R.J., Endean, R., 1984. Mode of action of ciguatoxin from the Spanish Mackerel, Scomberomorus commersoni, on the guinea-pig ileum and vas deferens. J. Pharmacol. Exp. Ther. 228, 756-760.

Lewis, R.J., Sellin, M., Poli, M.A., Norton, R.S., MacLeod, J.K., Sheil, M.M., 1991. Purification and characterization of ciguatoxins from moray eel (Lycodontis javanicus, Muraenidae). Toxicon 29, 1115-1127.

Lombet, A., Bidard, J.N., Lazdunski, M., 1987. Ciguatoxin and brevetoxins share a common receptor site on the neuronal voltage-dependent $\mathrm{Na}+$ channel. FEBS Lett. 219, 355-359.

Luo, H.D., Bai, Y.Y., Zhou, N., 2011. Study of three ciguatera fish poisoning cases in Xiamen city, in 2005. Zhonghua Yu Fang Yi Xue Za Zhi 45, 512-515.

Mitchell, K., 1976. Ciguatera. Med. J. Aust. 2, 660.

Morris, P.D., Campbell, D.S., Freeman, J.I., 1990. Ciguatera fish poisoning: an outbreak associated with fish caught from North Carolina coastal waters. South. Med. J. 83, 379-382.

Morton, R.A., Burklew, M.A., 1970. Incidence of ciguatera in barracuda from the west coast of Florida. Toxicon 8, 317-318.

Murata, M., Legrand, A.M., Ishibashi, Y., Yasumoto, T., 1990. Structures and configurations of ciguatoxin from the moray eel Gymnothorax javanicus and its likely precursor from the dinoflagellate Gambierdiscus toxicus. J. Am. Chem. Soc. 112, 4380-4386.

Nunez, D., Matute, P., Garcia, A., Garcia, P., Abadia, N., 2012. Outbreak of ciguatera food poisoning by consumption of amberjack (Seriola spp.) in the Canary Islands, May 2012. Euro Surveillance 17.

Oshiro, N., Yogi, K., Asato, S., Sasaki, T., Tamanaha, K., Hirama, M., Yasumoto, T., Inafuku, Y., 2010. Ciguatera incidence and fish toxicity in Okinawa, Japan. Toxicon 56, 656-661.

Otero, P., Perez, S., Alfonso, A., Vale, C., Rodriguez, P., Gouveia, N.N., Gouveia, N., Delgado, J., Vale, P., Hirama, M., Ishihara, Y., Molgo, J., Botana, L.M., 2010. First toxin profile of ciguateric fish in Madeira Arquipelago (Europe). Anal. Chem. 82, 6032-6039.
Poli, M.A., Lewis, R.J., Dickey, R.W., Musser, S.M., Buckner, C.A., Carpenter, L.G., 1997. Identification of Caribbean ciguatoxins as the cause of an outbreak of fish poisoning among U.S. soldiers in Haiti. Toxicon 35, 733-741.

Pottier, I., Hamilton, B., Jones, A., Lewis, R.J., Vernoux, J.P., 2003. Identification of slow and fast-acting toxins in a highly ciguatoxic barracuda (Sphyraena barracuda) by HPLC/MS and radiolabelled ligand binding. Toxicon 42, 663-672.

Pottier, I., Vernoux, J.P., Jones, A., Lewis, R.J., 2002. Analysis of toxin profiles in three different fish species causing ciguatera fish poisoning in Guadeloupe, French West Indies. Food Addit. Contam. 19, 1034-1042.

Pottier, I., Vernoux, J.P., Jones, A., Lewis, R.J., 2002. Characterisation of multiple Caribbean ciguatoxins and congeners in individual specimens of horse-eye jack (Caranx latus) by high-performance liquid chromatography/mass spectrometry. Toxicon 40, 929-939.

Ramialiharisoa, A., Razafindraktoto, L.R., Rasoanaivo, P., 1997. Shark poisoning in Madagascar: a case report. Afr. J. Health Sci. 4, 33-34.

Rongo, T., van Woesik, R., 2013. The effects of natural disturbances, reef state, and herbivorous fish densities on ciguatera poisoning in Rarotonga, southern Cook Islands. Toxicon 64, 87-95.

Sanner, B.M., Rawert, B., Henning, B., Zidek, W., 1997. Ciguatera fish poisoning following travel to the tropics. Z. Gastroenterol. 35, 327-330.

Schlaich, C., Hagelstein, J.G., Burchard, G.D., Schmiedel, S., 2012. Outbreak of ciguatera fish poisoning on a cargo ship in the port of hamburg. J. Travel. Med. 19, 238-242.

Schlumberger, S., Mattei, C., Molgo, J., Benoit, E., 2010. Dual action of a dinoflagellate-derived precursor of Pacific ciguatoxins (P-CTX-4B) on voltage-dependent $\mathrm{K}(+)$ and $\mathrm{Na}(+)$ channels of single myelinated axons. Toxicon 56, 768-775.

Schnorf, H., Taurarii, M., Cundy, T., 2002. Ciguatera fish poisoning: a double-blind randomized trial of mannitol therapy. Neurology 58, 873-880.

Senthilkumaran, S., Meenakshisundaram, R., Michaels, A.D., Suresh, P., Thirumalaikolundusubramanian, P., 2011. Cardiovascular complications in ciguatera fish poisoning: a wake-up call. Heart Views 12, $166-168$.

Shoemaker, R.C., House, D., Ryan, J.C., 2010. Defining the neurotoxin derived illness chronic ciguatera using markers of chronic systemic inflammatory disturbances: a case/control study. Neurotoxicol. Teratol. 32, 633-639.

Skinner, M.P., Brewer, T.D., Johnstone, R., Fleming, L.E., Lewis, R.J., 2011. Ciguatera fish poisoning in the Pacific Islands (1998 to 2008). PLoS. Negl. Trop. Dis. 5, e1416.

Stewart, M.P., 1991. Ciguatera fish poisoning: treatment with intravenous mannitol. Trop. Dr. 21, 54-55.

Van Itallie, T.B., Hashim, S.A., Crampton, R.S., Tennent, D.M., 1961. The treatment of pruritus and hypercholesteremia of primary biliary cirrhosis with cholestyramine. N. Engl. J. Med. 265, 469-474.

Vernoux, J.P., Lewis, R.J., 1997. Isolation and characterisation of Caribbean ciguatoxins from the horse-eye jack (Caranx latus). Toxicon 35, 889-900.

Vetter, I., Touska, F., Hess, A., Hinsbey, R., Sattler, S., Lampert, A., Sergejeva, M., Sharov, A., Collins, L.S., Eberhardt, M., Engel, M., Cabot, P.J., Wood, J.N., Vlachova, V., Reeh, P.W., Lewis, R.J., Zimmermann, K., 2012. Ciguatoxins activate specific cold pain pathways to elicit burning pain from cooling. EMBO J. 31, 3795-3808.

Vigneau, J.F., Kierzek, G., Dumas, F., Pourriat, J.L., 2008. Ciguatera: recrudescence of symptomatology of a previous intoxication. Ann. Fr. Anesth. Reanim. 27, 863-864.

Whitley, G.P., 1943. Poisonous and harmful fishes. Counc. Sci. Ind. Res. Bull. 159.

Wong, C.K., Hung, P., Lee, K.L., Kam, K.M., 2005. Study of an outbreak of ciguatera fish poisoning in Hong Kong. Toxicon 46, 563-571.

Woofter, R.T., Ramsdell, J.S., 2007. Distribution of Brevetoxin to Lipoproteins in human plasma. Toxicon 49, 1010-1018.

Yogi, K., Oshiro, N., Inafuku, Y., Hirama, M., Yasumoto, T., 2011. Detailed LC-MS/MS analysis of ciguatoxins revealing distinct regional and species characteristics in fish and causative alga from the Pacific. Anal. Chem. 83, 8886-8891.

Yogi, K., Oshiro, N., Matsuda, S., Sakugawa, S., Matsuo, T., Yasumoto, T. 2013. Toxin profiles in fish implicated in ciguatera fish poisoning in Amami and Kakeroma islands, Kagoshima prefecture, Japan. Shokuhin Eiseigaku Zasshi 54, 385-391.

Zimmermann, K., Deuis, J.R., Inserra, M., Collins, L.S., Namer, B., Cabot, P.J., Reeh, P.W., Lewis, R.J., Vetter, I., 2013. Analgesic treatment of ciguatoxin-induced cold allodynia. Pain 154 (10), 1999-2006.

Zimmermann, K., Eisenblätter, A., Vetter, I., Ebbecke, M., Friedemann, M., Desel, H., 2014. Imported tropical fish causes ciguatera fish poisoning in Germany. Dtsch. Med. Wochenschr. (in press; article in German). 